\title{
Bacterioplankton dynamics in the York River estuary: primary influence of temperature and freshwater inputs
}

\author{
Gary E. Schultz Jr. ${ }^{1, *}$, Edward D. White III $^{2}$, Hugh W. Ducklow ${ }^{3}$ \\ ${ }^{1}$ Texas A \& M University-Galveston, 5007 Avenue U, Galveston, Texas 77551, USA \\ ${ }^{2}$ Department of Mathematics and Statistics, Air Force Institute of Technology, Building 640, 2950 P Street, \\ Wright-Patterson Air Force Base, Ohio 45433-7765, USA \\ ${ }^{3}$ School of Marine Science, College of William and Mary, PO Box 1346, Gloucester Point, Virginia 23062, USA
}

\begin{abstract}
Bacterial community dynamics were investigated over seasonal and basin scales within the York River estuary, Virginia. Variables describing bacterioplankton dynamics were measured at 6 stations spanning the entire salinity gradient ( 0 to ca. 20 psu over $60 \mathrm{~km}$ ). Samples were collected monthly from June 1996 through May 1997 and every other month from June 1997 through May 1998. Bacterial abundance and production were high throughout the estuary. Bacterial abundance ranged from $4.4 \times 10^{8}$ to $1.3 \times 10^{10}$ cells $\mathrm{l}^{-1}$. Incorporation of ${ }^{3} \mathrm{H}$-thymidine ranged from 10 to $863 \mathrm{pmol}^{-1} \mathrm{~h}^{-1}$ while ${ }^{3} \mathrm{H}$-leucine incorporation rates ranged from 25 to $1963 \mathrm{pmol} \mathrm{l}^{-1} \mathrm{~h}^{-1}$. A strong relationship between bacterial properties and temperature was found with clear seasonal trends. On a basin scale, bacterial properties were strongly related to changes in salinity, suggesting that freshwater inputs and estuarine circulation controlled the distribution of bacterial abundance and activity in the river. Although there was a great deal of variability from month to month, 2 opposing trends were consistently found: bacterial abundance increased from freshwater to the mouth of the river, while incorporation rates decreased from freshwater to the mouth. These patterns imply a strong landward gradient in specific growth rates, and thus a close match between production and removal near the freshwater endmember and throughout the estuary.
\end{abstract}

KEY WORDS: Bacterioplankton · Estuary $\cdot$ Environmental controls $\cdot$ Spatial patterns $\cdot$ Temporal patterns

\section{INTRODUCTION}

Estuaries exist on the margins between the coastal ocean and land, and mediate the export of dissolved organic carbon (DOC) and particulate organic carbon (POC) to the ocean (Winter et al. 1996). Bacterial standing stock and production is high in estuaries relative to other marine systems (Ducklow \& Carlson 1992, Ducklow \& Shiah 1993). Bacteria respire and remineralize organic matter (Nagata \& Kirchman 1991, Miller et al. 1995) and are capable of consuming a large por-

*Email: schultzg@tamug.tamu.edu tion of autotrophic production in aquatic systems (Cole et al. 1988). Bacteria may also be grazed, thus transferring their energy to at least the next trophic level within the estuary (Sanders et al. 1989). Thus, estuarine bacterial activity may play an important role in estuarine processing of organic matter.

Biological factors such as substrate supply, grazing and viral lysis, as well as physical factors such as temperature and circulation, may shape bacterial distribution within an estuary. Estuaries, by nature, are dynamic regions characterized by steep gradients in temperature, salinity and nutrient concentrations (Day et al. 1989). The complex interactions between these environmental parameters make it difficult to deter- 
mine which factor, or set of factors, is most important in the control of bacterial dynamics; however, several controls of bacterial properties have been found. Topdown controls such as grazing are thought to set limits on bacterial biomass and abundance (Billen 1990, Boissonneault-Cellineri et al. 2001), while limits on bacterial growth rates are thought to be set by bottomup factors such as substrate supply and temperature (White et al. 1991, Shiah \& Ducklow 1994, 1995, Revilla et al. 2000). These factors are influenced by physical processes such as freshwater flow, light intensity, storm frequency, circulation effects and other physical processes (Day et al. 1989) and may vary seasonally in an estuary.

Phytoplankton may also strongly influence bacterial dynamics. Previous studies of non-estuarine aquatic ecosystems have found positive relationships between bacterial production and primary phytoplankton production (Lancelot \& Billen 1984, Cole et al. 1988, White et al. 1991) indicating that primary production ultimately provides most of the carbon needed for bacterial production in these settings. In many estuarine systems, however, the relationship between bacterial and primary production is weak or non-existent (Ducklow \& Kirchman 1983, Painchaud \& Therriault 1989, Findlay et al. 1991, Ducklow \& Shiah 1993; but see Goosen et al. 1997). Of the few studies of estuarine systems conducted over an entire year or longer, none reported high covariation between bacterial and phytoplankton properties (Wright et al. 1987, Ducklow $\&$ Shiah 1993). These results suggest that bacterioplankton in estuaries utilize some terrestrially derived carbon rather than relying solely on phytoplankton

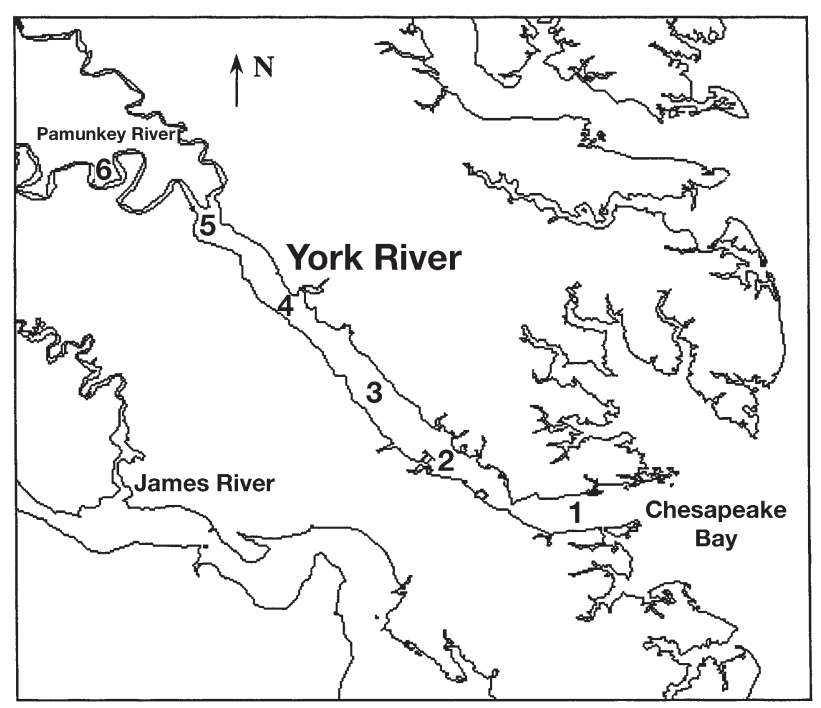

Fig. 1. Map of sampling station locations. The York River estuary is located in Virginia, USA at approximately $37^{\circ} \mathrm{N}, 76^{\circ} \mathrm{W}$ produced carbon. Indeed, estuarine bacteria have been shown to utilize allochthonous inputs of organic material (Coffin et al. 1989, Hullar et al. 1996, Kelley \& Coffin 1998), as well as phytoplankton-produced DOM (Chrost \& Faust 1983, Gomes et al. 1991).

There have been several studies of bacterial dynamics in the major tributaries of the Chesapeake Bay (Rublee et al. 1984, Gilmour et al. 1987, Shiah \& Ducklow 1995). In the York and James Rivers, Ducklow (1982), Eldridge \& Sieracki (1993), and Koepfler et al. (1993) all studied short-term, event-scale processes including the effect of the spring-neap tidal cycle on bacterial abundance and activity at the mouth. However, there have been no comparable seasonal and basin scale studies on this system. In this study, spatial and temporal patterns of heterotrophic bacterioplankton abundance and activity were investigated to determine those environmental factors that were most strongly related to, and thus potentially controlled, bacterial abundance and production. Data are presented on mean monthly, seasonal and annual patterns of bacterial abundance and production.

\section{MATERIALS AND METHODS}

Study site. The York River is a sub-estuary of the Chesapeake Bay, lying between the James and Rappahannock Rivers, with a drainage area of $8368 \mathrm{~km}^{2}$ (the Chesapeake Bay Program, www.chesapeakebay.net). The York flows in a southeasterly direction approximately $50 \mathrm{~km}$ from the confluence of the Pamunkey and Mattaponi rivers at West Point, Virginia to the mouth near Yorktown, where it empties into Chesapeake Bay (Fig. 1). The Pamunkey has a drainage area of approximately $3773 \mathrm{~km}^{2}$ and contributes about $70 \%$ of the flow to the York River estuary (United States Geological Survey [USGS], http://water.usgs.gov). Salt and freshwater marshes border the Pamunkey throughout the study area. The entire sampling area is tidally influenced with a mean tidal range of 0.61 to $0.88 \mathrm{~m}$ (Bender 1986). Brackish water extends approximately $60 \mathrm{~km}$ upstream from the mouth. The York is one of the most pristine sub-estuarine systems in the entire Chesapeake Bay system (Virginia Dept of Environmental Quality 1994). The makeup of the York basin is approximately $60 \%$ forest, $21 \%$ agriculture, $7 \%$ wetlands, $2 \%$ barren, $2 \%$ developed, with the remainder covered by water (the Chesapeake Bay Program, www.chesapeakebay.net).

Sample collection. Samples were collected monthly at 6 stations along the salinity gradient of the York River (Fig. 1) from June 1996 through May 1997. Samples were then collected every other month until May 1998. Stations were approximately $9 \mathrm{~km}$ apart 
with Stn 1 located at the mouth of the York and Stn 6 located in freshwater in the Pamunkey River $60 \mathrm{~km}$ from the mouth. At each station, samples were collected $1 \mathrm{~m}$ below the surface and $1 \mathrm{~m}$ above the bottom using a clean (acid-washed) 2.51 Niskin bottle. Bacterial cell abundance, bacterial activity, chlorophyll $a$, temperature, salinity, DOC, dissolved organic nitrogen (DON), dissolved oxygen (DO), total dissolved nitrogen (TDN), nitrate $\left(\mathrm{NO}_{3}^{-}\right)$, nitrite $\left(\mathrm{NO}_{2}{ }^{-}\right)$and ammonium $\left(\mathrm{NH}_{4}{ }^{+}\right)$were measured on each sample.

Bacterial cell abundance and biovolume measurements. Samples for bacterial abundance and biovolume were immediately preserved with $0.2 \mu \mathrm{m}$ filtered glutaraldehyde (Sigma) at a final concentration of $2 \%$. Samples were filtered onto $0.2 \mu \mathrm{m}$ black polycarbonate filters (Poretics) with mixed-ester backing filters (MSI) to ensure even distribution of cells. As the samples were being filtered, acridine orange (Sigma) solution (final concentration $0.005 \%$ ) was added to stain the cells for viewing (Hobbie et al. 1977). Samples were mounted on glass slides in Resolve ${ }^{\mathrm{TM}}$ immersion oil and frozen $\left(-80^{\circ} \mathrm{C}\right)$ until examination.

All slides were analyzed by epifluorescence microscopy using a Zeiss Axiophot microscope at $1613 \times$ with a blue BP 450-490 excitation filter and an LP520 barrier filter. To estimate biovolume, images were taken with a Dage-MTI Nuvicon video camera connected to the Axiophot microscope through a Dage Gen-II image intensifier. Images were processed and analyzed using the Zeiss Vidas Videoplan Image Analysis system. Cell volumes were estimated using the algorithm of Baldwin \& Bankston (1988).

Bacterial production $-{ }^{3} \mathrm{H}$-thymidine and ${ }^{3} \mathrm{H}$-leucine incorporation. Bacterial production was estimated from $\left[{ }^{3} \mathrm{H}\right.$-methyl]-thymidine and $\left[4,5-{ }^{3} \mathrm{H}\right]-$ leucine incorporation (Fuhrman \& Azam 1982, Kirchman et al. 1985). Water was collected and $1.7 \mathrm{ml}$ of the sample were added to $2.0 \mathrm{ml}$ microcentrifuge tubes containing either $25 \mathrm{nM}$ thymidine or $40 \mathrm{nM}$ leucine. Samples were incubated at near in situ temperature $\left( \pm 2.0^{\circ} \mathrm{C}\right)$ for approximately $1 \mathrm{~h}$. Incubations were stopped by adding $100 \mu$ l of ice cold $100 \%$ trichloroacetic acid (TCA; Fisher). Blanks were prepared by the addition of TCA immediately before addition of the sample. Samples were processed per the microcentrifugation method of Smith \& Azam (1992) immediately upon returning to the lab.

To determine the sampling uncertainty, triplicate Niskin samples were collected in March 1998 at Stns 2 and 5 as well as on several other occasions off the VIMS (Virginia Institute of Marine Science) pier (data not shown). For bacterial cell abundance, cell biovolume, thymidine incorporation rates (TdR) and leucine incorporation rates (Leu), the coefficient of variation between the 3 samples in most cases was lower than
$10 \%$ and in all cases lower than $15 \%$. Specific incorporation rates ( $\mathrm{TdR}$ cell ${ }^{-1}$ and Leu cell ${ }^{-1}$ ) were calculated as indices of specific growth and biomass turnover rates, respectively.

Conversion factors. To derive bacterial cell production from TdR, the conversion factor for an estuary of $1.1 \times 10^{18}$ cells $\mathrm{mol}^{-1}$ of thymidine incorporated was used (Riemann et al. 1987). To convert cell measurements to units of carbon, we used a volumetric conversion factor to ensure that differences in cell size within the estuary were incorporated into the estimated pro-

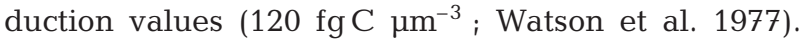
Thus, bacterial production values were calculated from TdR and average cell biovolume for each sample. A conversion factor of $3.1 \mathrm{kgC} \mathrm{mol}^{-1}$ was used to convert from Leu to bacterial production (Simon \& Azam 1989).

Chlorophyll a. Chlorophyll a was determined by DMSO/acetone extraction according to Burnison (1980).

Environmental parameters. The Analytical Lab at the Virginia Institute of Marine Science analyzed dissolved organic matter and inorganic nutrients, which were collected and measured as follows:

DO concentration was analyzed using Winkler titration (Carpenter 1965). Salinity was measured with a salinometer. DOC was determined by high temperature catalytic oxidation techniques (Williams et al. 1993) using a Shimadzu TOC-5000. TDN was measured by persulfate digestion (Parsons et al. 1984). DIN was defined as $\mathrm{NO}_{2}{ }^{-}$ and $\mathrm{NO}_{3}{ }^{-}$plus $\mathrm{NH}_{4}{ }^{+}$. $\mathrm{NO}_{2}{ }^{-}$and $\mathrm{NO}_{3}{ }^{-}$were determined by $\mathrm{Cd}-\mathrm{Cu}$ reduction (Parsons et al. 1984) and $\mathrm{NH}_{4}{ }^{+}$was determined by the phenolhypochlorite method (Parsons et al. 1984). DON was defined as the difference between TDN and DIN. All samples other than those for oxygen and salinity were stored on ice immediately after collection until returning to the lab.

Statistical methods. To determine the environmental factors that were most closely related to bacterial properties (abundance, cell volume, TdR incorporation, Leu incorporation, TdR incorporation per cell, and Leu incorporation per cell), multiple regression analysis using a full versus reduced F-test methodology was run on the entire unsorted data set using the JMP software package (version 4.04; SAS Institute). Because the variance of these response variables was not constant, the natural log of the response variables was used for analysis.

\section{RESULTS}

\section{Environmental properties}

In most cases, bottom water properties closely followed surface water properties. All general trends 
reported below are for both surface and bottom waters unless otherwise noted. Salinity values ranged from $0.3 \pm 0.9$ (annual mean \pm SD) at Stn 6 (upriver) to $16.3 \pm$ 2.7 at Stn 1 (the mouth). For any given sampling period, water temperature varied less than $1.5^{\circ} \mathrm{C}$ along the length of the salinity gradient. Seasonally, temperature ranged from $\sim 5^{\circ} \mathrm{C}$ in the winter months to $>25^{\circ} \mathrm{C}$ in the summer (Fig. 2). DOC concentrations ranged from $3.70 \pm 0.34 \mathrm{mg} \mathrm{C}^{-1}$ (annual mean $\pm \mathrm{SD}$ ) at $\mathrm{Stn} 1$ to $5.20 \pm 1.70 \mathrm{mg} \mathrm{C}^{-1}$ at $\mathrm{Stn} 6$. DON concentrations ranged from $0.26 \pm 0.06 \mathrm{mg} \mathrm{N} \mathrm{l}^{-1}$ at Stn 1 to $0.30 \pm$ $0.07 \mathrm{mg} \mathrm{N}^{-1}$ at Stn 6 (Fig. 2). DOC and DON concentrations were generally highest in the late summer/early fall with lowest concentrations in the winter months (Fig. 2). DIN concentrations increased with distance upstream. Seasonally, DIN concentrations were more variable than DOC and DON, but were generally lowest during the warm water months and highest in the cold water months. Chlorophyll $a$ concentrations in the York River were lowest at each end of the estuary (Stns 6 and $1 ; 17.4 \pm 21.5 \mu \mathrm{g} \mathrm{C} \mathrm{l^{-1 }}$ and $19.7 \pm 12.1 \mu \mathrm{g} \mathrm{Cl}^{-1}$, respectively; Fig. 2). The highest mean chlorophyll a concentrations were found in the mid-estuary at Stns 3 and 4 (31.6 \pm 34.8 and $40.5 \pm$ $45.9 \mu \mathrm{g} \mathrm{C} \mathrm{l}^{-1}$, respectively). A summer-long phytoplankton bloom occurred in the upper river (Stns 4, 5 and 6; Fig. 2) from May through October 1997. A spring bloom occurred at Stns 3 and 4 in February and March 1997 (Fig. 2). Sporadic smaller scale blooms occurred at other times and locations (Fig. 2).

\section{Bacterial properties of the York River: temporal patterns}

Bacterial cell abundance exhibited a seasonal cycle at all stations, corresponding to the annual cycle of temperature (Fig. 2). Cell abundance was greatest during the summer months and lowest during the winter months. Bacterial production (as measured by TdR incorporation) showed the same general seasonal pattern as bacterial abundance, but the largest TdR incorporation rates occurred in the spring and fall (Fig. 2, Table 1). Leucine production (as measured by Leu incorporation) was highest in the summer and lowest in the winter, with the highest Leu incorporation rates found in July of 1997 (Fig. 2, Table 1).

\section{Relationships between bacterial properties and chemical and physical factors}

Multiple regression analysis indicated that except for cell abundance, there was no significant difference between surface and bottom samples for bacterial properties. Salinity was significantly related to all properties other than Leu incorporation, and temperature was significantly related to all properties except TdR cell ${ }^{-1}$. But no single environmental parameter was significantly related $(p<0.05$ ) to all bacterial properties (Table 2). Year was significantly related to all properties except cell volume and Leu incorporation (Table 2), indicating significant seasonal and interannual variability of bacterial dynamics in the York River. Neither bacterial abundance nor bacterial production derived from TdR incorporation rates was significantly correlated with chlorophyll a (Table 2), but a weak relationship between Leu incorporation and chlorophyll a was found. The molar DOC:DON ratio was significantly related to both $\mathrm{TdR}$ cell ${ }^{-1}$ and Leu cell $^{-1}$ while the molar DOC:TDN ratio was not significantly related to any measured bacterial property (Table 2). TdR incorporation and Leu incorporation were not significantly related to DOC:DON or DOC:TDN (data not shown).

\section{Seasonal patterns}

To examine seasonal trends, cell-specific TdR incorporation rates $\left(\mathrm{TdR}\right.$ cell ${ }^{-1}$ ) and Leu incorporation rates (Leu cell ${ }^{-1}$ ) were determined and investigated. The year was divided by temperature and season into 4 periods and seasonal averages for TdR cell ${ }^{-1}$ and Leu cell $^{-1}$ were calculated for each station (Table 1). TdR cell $^{-1}$ was lowest in the winter and highest in the fall and spring at all stations except Stn 4, where the summer rate was slightly higher than that in the fall, and Stn 5, where summer had the lowest TdR cell ${ }^{-1}$ (Table 1). Leu cell ${ }^{-1}$ generally showed the same pattern as TdR cell ${ }^{-1}$ (Table 1), but the magnitude of the differences between summer, spring and fall Leu cell $^{-1}$ values was not as great.

To further examine the relationships between bacterial properties, temperature and other environmental factors in the entire estuary over seasonal time-scales,

Fig. 2. (Across and following page.) (a) Bacterial abundance, TdR and Leu incorporation rates, and chlorophyll a at each station (St) over the sampling period (June 1996-May 1998). (b) Bacterial cell volume, DOC, DON and DIN concentrations at each station over the sampling period (June 1996-May 1998). DON was defined as the difference between TDN and DIN. DIN is the sum of $\mathrm{NO}_{2}{ }^{-}+\mathrm{NO}_{3}{ }^{-}$and $\mathrm{NH}_{4}{ }^{+}$. Temperature at each station is shown by superimposed dotted line. Station numbers are in the upper right of each chart. Values represent samples collected $1 \mathrm{~m}$ below the surface. Bottom values typically follow surface values. TdR incorporation rate at Stn 6 for May 1998 sample is off the chart $\left(798 \mathrm{pmol} \mathrm{l}^{-1} \mathrm{~h}^{-1}\right)$. Ranges are held constant for all properties at all stations to show station to station differences 
a
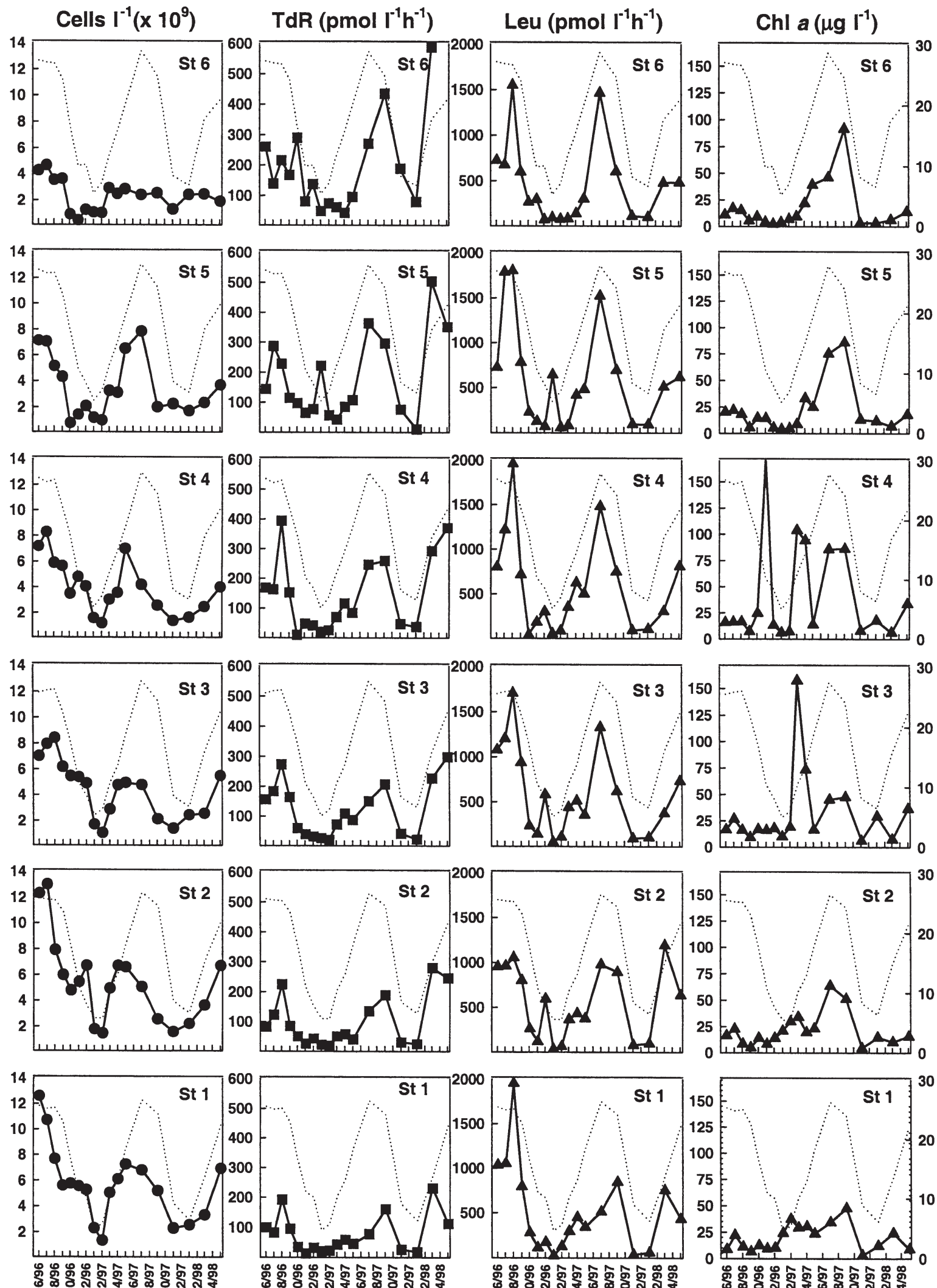


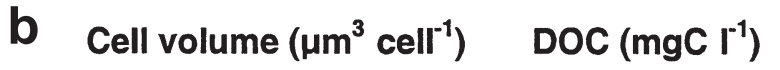
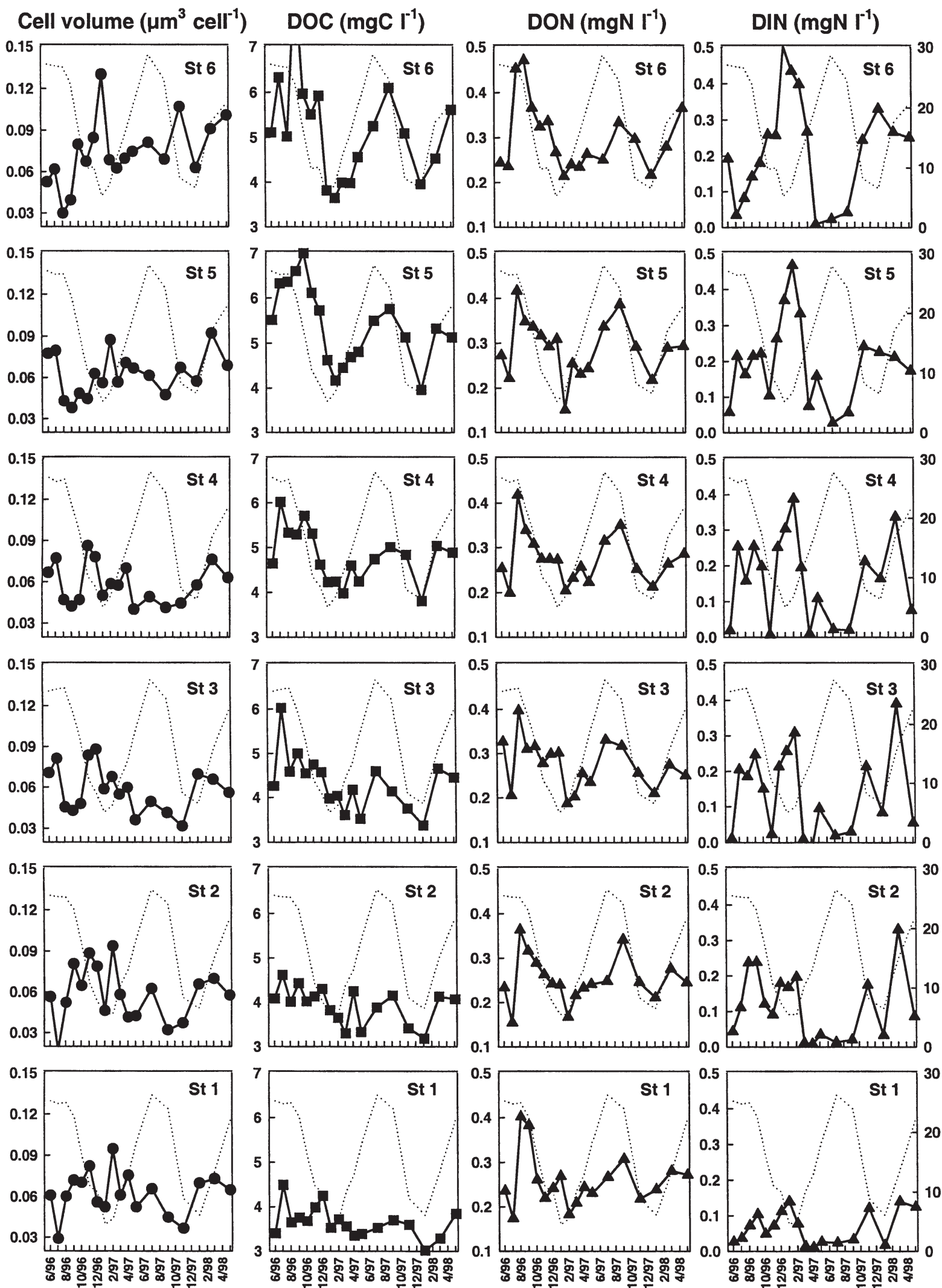

Fig. 2 (continued) 
Table 1. Bacterial production and growth rates grouped by season, for surface samples. Fall values are the mean at each station for September, October, and November $\left(10^{\circ} \mathrm{C}<\right.$ temperature $\left.<25^{\circ} \mathrm{C}\right)$; winter values are the mean at each station for December, January, and February (temperature $<10^{\circ} \mathrm{C}$ ); spring values are the mean at each station for March, April, and May $\left(10^{\circ} \mathrm{C}<\right.$ temperature $<25^{\circ} \mathrm{C}$ ); and summer values are the mean at each station for June, July, and August (temperature $>25^{\circ} \mathrm{C}$ ). Values in parentheses are standard deviation of the mean

\begin{tabular}{|c|c|c|c|c|c|c|c|}
\hline Stn & Season & $\begin{array}{l}\text { Temp. } \\
\left({ }^{\circ} \mathrm{C}\right)\end{array}$ & $\begin{array}{l}\text { Abundance } \\
\left(10^{9} \text { cells } 1^{-1}\right)\end{array}$ & $\begin{array}{c}\mathrm{TdR} \\
\left(\mathrm{pmol}^{-1} \mathrm{~h}^{-1}\right)\end{array}$ & $\begin{array}{c}\text { Leu } \\
\left(\mathrm{pmol} \mathrm{l}^{-1} \mathrm{~h}^{-1}\right)\end{array}$ & $\begin{array}{c}\text { TdR cell }{ }^{-1} \\
\left(\mathrm{pmol} \mathrm{cell}{ }^{-1} \mathrm{~h}^{-1} \times 10^{-8}\right)\end{array}$ & $\begin{array}{c}\text { Leu cell }{ }^{-1} \\
\left(\mathrm{pmol} \mathrm{cell}{ }^{-1} \mathrm{~h}^{-1} \times 10^{-8}\right)\end{array}$ \\
\hline 6 & Summer & $27.3(1.0)$ & $3.7(0.9)$ & $222(52)$ & 1105 (403) & $6.6(3.0)$ & $34.0(19.2)$ \\
\hline 6 & Fall & $16.6(6.7)$ & $1.8(1.2)$ & 233 (121) & 376 (195) & $17.4(9.0)$ & $29.3(20.4)$ \\
\hline 6 & Winter & $7.2(1.5)$ & $1.4(0.6)$ & $85(32)$ & 87 (11) & $6.5(2.9)$ & $6.7(1.8)$ \\
\hline 6 & Spring & $17.0(3.0)$ & $2.5(0.4)$ & 317 (315) & 298 (166) & $14.5(15.9)$ & $12.8(8.4)$ \\
\hline 5 & Summer & $27.0(0.7)$ & $6.8(1.0)$ & 256 (80) & 1461 (438) & $3.8(1.0)$ & $22.5(9.0)$ \\
\hline 5 & Fall & $16.5(6.4)$ & $2.2(1.2)$ & $130(85)$ & 388 (291) & $7.6(5.0)$ & $19.2(11.5)$ \\
\hline 5 & Winter & $6.7(1.0)$ & $1.5(0.4)$ & $92(79)$ & $220(247)$ & $7.3(6.9)$ & $17.5(21.5)$ \\
\hline 5 & Spring & $16.8(3.2)$ & $3.8(1.4)$ & 219 (179) & 425 (182) & $7.3(7.7)$ & $12.4(6.8)$ \\
\hline 4 & Summer & $26.8(0.6)$ & $6.4(1.5)$ & 243 (93) & 1367 (422) & $4.2(2.1)$ & $23.7(10.8)$ \\
\hline 4 & Fall & $16.3(6.3)$ & $3.6(1.5)$ & 104 (91) & 358 (310) & $3.5(3.5)$ & $10.8(10.0)$ \\
\hline 4 & Winter & $6.7(1.2)$ & $2.1(1.1)$ & 32 (9) & $139(96)$ & $1.7(0.5)$ & $6.3(1.6)$ \\
\hline 4 & Spring & $16.5(3.6)$ & $4.0(1.6)$ & $187(122)$ & $521(184)$ & $5.6(4.2)$ & $13.8(4.6)$ \\
\hline 3 & Summer & $26.2(0.8)$ & $7.0(1.4)$ & 191 (49) & $1330(234)$ & $2.7(0.5)$ & $19.7(5.1)$ \\
\hline 3 & Fall & $16.5(6.3)$ & $4.1(1.9)$ & $103(70)$ & $404(324)$ & $3.4(3.3)$ & $11.5(9.7)$ \\
\hline 3 & Winter & $6.4(1.2)$ & $2.5(1.5)$ & $25(4)$ & $211(215)$ & $1.3(0.5)$ & $7.3(3.8)$ \\
\hline 3 & Spring & $16.1(4.0)$ & $4.1(1.2)$ & 159 (89) & 482 (138) & $4.2(2.7)$ & $12.2(2.9)$ \\
\hline 2 & Summer & $25.6(0.4)$ & $9.6(3.3)$ & $142(52)$ & $989(40)$ & $1.8(1.0)$ & $12.0(4.9)$ \\
\hline 2 & Fall & $16.8(6.4)$ & $4.1(1.7)$ & $77(60)$ & 433 (346) & $2.5(2.5)$ & $12.2(12.0)$ \\
\hline 2 & Winter & $6.3(0.9)$ & $3.0(2.1)$ & $28(9)$ & 199 (230) & $1.1(0.3)$ & $5.0(2.5)$ \\
\hline 2 & Spring & $15.6(4.0)$ & $5.7(1.2)$ & 135 (105) & 603 (313) & $2.8(2.7)$ & $12.4(10.3)$ \\
\hline 1 & Summer & $25.4(1.4)$ & $9.4(2.3)$ & $113(46)$ & 1139 (518) & $1.3(0.7)$ & $12.8(7.4)$ \\
\hline 1 & Fall & $16.5(6.2)$ & $4.9(1.3)$ & 66 (55) & 415 (340) & $1.4(1.0)$ & $7.8(6.2)$ \\
\hline 1 & Winter & $6.5(2.2)$ & $2.9(1.5)$ & $24(5)$ & 97 (58) & $1.0(0.4)$ & $4.1(3.3)$ \\
\hline 1 & Spring & $15.4(4.3)$ & $5.7(1.4)$ & 99 (71) & 456 (160) & $2.2(2.4)$ & $9.4(6.7)$ \\
\hline
\end{tabular}

Table 2. F-ratios and p-values of multiple regressions run among bacterial properties and environmental factors. Top number in each case is the $F$-ratio and the bottom number is the $\mathrm{p}$-value. The environmental parameter with the largest $F$-ratio for each column exerts the greatest degree of control over that bacterial property. Sample year was from June 1996 to May 1997 and from June 1997 to May 1998. Blank spaces indicate no significant relationship ( $>$ > 0.05). As no significant relationship was found between bacterial properties and DIN, $\mathrm{NO}_{2}^{-}, \mathrm{NO}_{3}{ }^{-}$, or DOC:TDN, these have been omitted from the table

\begin{tabular}{|c|c|c|c|c|c|c|c|c|}
\hline & ln abundance & $\begin{array}{l}\text { In abundance } \\
\text { (surface) }\end{array}$ & $\begin{array}{l}\text { In abundance } \\
\text { (bottom) }\end{array}$ & $\begin{array}{c}\ln \mathrm{TdR} \\
\text { incorporation }\end{array}$ & $\begin{array}{c}\ln \text { Leu } \\
\text { incorporation }\end{array}$ & $\begin{array}{c}\text { Cell } \\
\text { volume }\end{array}$ & $\begin{array}{c}\ln \\
\text { TdR cell }{ }^{-1}\end{array}$ & $\begin{array}{c}\ln \\
\text { Leu cell }{ }^{-1}\end{array}$ \\
\hline $\mathrm{R}^{2}$ of model & 0.58 & 0.64 & 0.53 & 0.66 & 0.71 & 0.27 & 0.60 & 0.49 \\
\hline Year & $\begin{array}{c}46.5 \\
<0.0001\end{array}$ & $\begin{array}{c}26.6 \\
<0.0001\end{array}$ & $\begin{array}{c}21.3 \\
<0.0001\end{array}$ & $\begin{array}{c}65.6 \\
<0.0001\end{array}$ & & & $\begin{aligned} & 117.8 \\
< & 0.0001\end{aligned}$ & $\begin{aligned} & 20.7 \\
< & 0.0001\end{aligned}$ \\
\hline Depth & $\begin{array}{c}8.1 \\
<0.01\end{array}$ & & & & & & & \\
\hline Temp. & $\begin{aligned} & 151.4 \\
<< & 0.0001\end{aligned}$ & $\begin{aligned} & 107.3 \\
< & 0.0001\end{aligned}$ & $\begin{aligned} & 51.6 \\
< & 0.0001\end{aligned}$ & $\begin{array}{c}240.2 \\
<0.0001\end{array}$ & $\begin{aligned} & 95.5 \\
< & 0.0001\end{aligned}$ & $\begin{aligned} & 4.9 \\
< & 0.05\end{aligned}$ & & $\begin{aligned} & 47.7 \\
< & 0.0001\end{aligned}$ \\
\hline Salinity & $\begin{aligned} & 24.5 \\
< & 0.0001\end{aligned}$ & $\begin{aligned} & 13.5 \\
< & 0.001\end{aligned}$ & $\begin{aligned} & 11.8 \\
< & 0.001\end{aligned}$ & $\begin{array}{c}27.3 \\
<0.0001\end{array}$ & & $\begin{array}{c}38.1 \\
<0.0001\end{array}$ & $\begin{array}{c}73.4 \\
<0.0001\end{array}$ & $\begin{aligned} & 22.0 \\
< & 0.0001\end{aligned}$ \\
\hline Chl a & & & & & $\begin{aligned} & 9.5 \\
< & 0.01\end{aligned}$ & & & \\
\hline DOC & & & & & $\begin{array}{c}9.2 \\
<0.01\end{array}$ & & $\begin{aligned} & 4.2 \\
< & 0.05\end{aligned}$ & $\begin{aligned} & 8.5 \\
< & 0.01\end{aligned}$ \\
\hline DON & $\begin{aligned} & 5.6 \\
< & 0.05\end{aligned}$ & $\begin{aligned} & 5.3 \\
< & 0.05\end{aligned}$ & & & $\begin{array}{c}8.9 \\
<0.01\end{array}$ & $\begin{aligned} & 6.3 \\
< & 0.05\end{aligned}$ & $\begin{array}{c}19.2 \\
<0.0001\end{array}$ & $\begin{array}{c}15.3 \\
<0.0001\end{array}$ \\
\hline $\mathrm{NH}_{4}^{+}$ & & & & $\begin{aligned} & 5.6 \\
< & 0.05\end{aligned}$ & & & & \\
\hline TDN & & & & $\begin{aligned} & 12.5 \\
< & 0.001\end{aligned}$ & & & & \\
\hline DOC:DON & $\begin{array}{c}4.1 \\
<0.05\end{array}$ & & & & $\begin{aligned} & 6.5 \\
< & 0.05\end{aligned}$ & $\begin{aligned} & 7.6 \\
< & 0.01\end{aligned}$ & $\begin{aligned} & 10.8 \\
< & 0.001\end{aligned}$ & $\begin{array}{c}10.9 \\
<0.01\end{array}$ \\
\hline
\end{tabular}


Table 3. Temporal scale relationships. F-ratios and p-values for all significant relationships between the mean values of each parameter over the entire estuary on each sampling date (see text for details). The top number in each case is the $F$-ratio and the bottom number is the $\mathrm{p}$-value. The environmental parameter with the largest $F$-ratio for each column exerts the greatest degree of control over that bacterial property. Blank spaces indicate no significant relationship ( $\mathrm{p}>0.05)$; no significant relationships were found at all for DOC:DON and DOC:TDN

\begin{tabular}{|c|c|c|c|c|c|}
\hline & $\begin{array}{c}\ln \\
\text { abundance }\end{array}$ & $\begin{array}{l}\ln \\
\mathrm{TdR}\end{array}$ & $\begin{array}{l}\ln \\
\text { Leu }\end{array}$ & $\begin{array}{l}\text { ln } \mathrm{TdR} \\
\text { cell }^{-1}\end{array}$ & $\begin{array}{c}\text { ln Leu } \\
\text { cell }^{-1}\end{array}$ \\
\hline $\mathrm{R}^{2}$ for model & 0.82 & 0.69 & 0.91 & 0.28 & 0.66 \\
\hline Temp. & $\begin{array}{c}46.8 \\
<0.0001\end{array}$ & $\begin{array}{c}34.9 \\
<0.0001\end{array}$ & $\begin{array}{c}116.7 \\
<0.0001\end{array}$ & & $\begin{aligned} & 49.0 \\
< & 0.0001\end{aligned}$ \\
\hline Salinity & $\begin{aligned} & 22.3 \\
< & 0.0001\end{aligned}$ & & $\begin{array}{c}20.3 \\
<0.0001\end{array}$ & & \\
\hline DOC & & & & $\begin{array}{c}8.4 \\
<0.01\end{array}$ & \\
\hline DON & & & $\begin{array}{c}5.1 \\
<0.05\end{array}$ & & \\
\hline DIN & $\begin{array}{c}36.1 \\
<0.0001\end{array}$ & 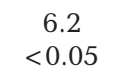 & & $\begin{aligned} & 5.6 \\
< & 0.05\end{aligned}$ & $\begin{aligned} & 13.6 \\
< & 0.001\end{aligned}$ \\
\hline Chl a & $\begin{aligned} & 13.7 \\
< & 0.001\end{aligned}$ & & $\begin{array}{c}9.5 \\
<0.01\end{array}$ & $\begin{array}{c}5.1 \\
<0.05\end{array}$ & $\begin{array}{c}13.6 \\
<0.001\end{array}$ \\
\hline
\end{tabular}

Table 4. Spatial scale relationships. F-ratios and p-values for all significant relationships between the mean values of each parameter at each station over the entire sampling period (see text for details). The top number in each case is the $F$-ratio and the bottom number is the $\mathrm{p}$-value. The environmental parameter with the largest $F$-ratio for each column exerts the greatest degree of control over that bacterial property. Blank spaces indicate no significant relationship $(p>0.05)$; no significant relationships were found at all for DON, DOC:DON, DOC:TDN and chl $a$

\begin{tabular}{|lccccc|}
\hline & $\begin{array}{c}\text { In } \\
\text { abundance }\end{array}$ & $\begin{array}{c}\ln \\
\text { TdR }\end{array}$ & $\begin{array}{c}\text { ln } \\
\text { Leu }\end{array}$ & $\begin{array}{c}\text { ln TdR } \\
\text { cell }^{-1}\end{array}$ & $\begin{array}{c}\text { ln Leu } \\
\text { cell }^{-1}\end{array}$ \\
\hline$R^{2}$ of model & 0.93 & 0.99 & 0.92 & 0.99 & 0.94 \\
Salinity & 52.5 & 49.0 & 92.9 & 33.7 & 7.4 \\
& $<0.0001$ & $<0.0001$ & $<0.0001$ & $<0.001$ & $<0.05$ \\
Temp. & 10.9 & 18.5 & 21.4 & & \\
& $<0.01$ & $<0.01$ & $<0.01$ & & \\
DOC & & & 30.9 & & \\
& & & $<0.001$ & & \\
DIN & & & & & \\
& & & & & \\
\end{tabular}

average monthly values for bacterial and environmental properties were analyzed. The mean values over all stations along the entire estuary for each measured parameter on each sampling date were determined (Table 3). This filtering process removed most of the variability related to space, and thus salinity, and allowed examination of seasonal patterns in the data. Multiple regressions were run among these station means of the data grouped by month (Table 3). Tem- perature was the environmental factor with the strongest effect on mean seasonal bacterial abundance, TdR incorporation, and Leu incorporation over the entire estuary (Table 3, Fig. 3).

\section{Spatial patterns}

To examine which environmental factors controlled bacterial properties along the salinity gradient regardless of season, the annual mean value of each parameter at each station over the entire course of the study was determined. Multiple regression analysis was then performed on these temporal-mean data. This aggregation removed much of the variability due to time, and thus temperature, and allowed examination of spatial patterns in the data (Table 4). All of the bacterial properties except TdR cell ${ }^{-1}$ and Leu cell $^{-1}$ were significantly related to temperature in this analysis, but strong correlations between salinity and temperature must be considered. The small change in mean temperature along the salinity gradient $\left(<1.5^{\circ} \mathrm{C}\right)$ is unlikely to have a discernable effect on the spatial relationships along the estuary. If temperature is neglected, bacterial properties in this model were most strongly related to salinity (Table 4).

In every month sampled, (18 total) the York River demonstrated opposing trends between bacterial abundance and TdR incorporation along the salinity gradient. Bacterial abundance increased with increasing salinity, while TdR incorporation decreased with increasing salinity (Figs. 2 \& 4).

The amount of carbon per newly created cell (NCC) was obtained by dividing the leucinebased biomass production $\left(\mathrm{g} \mathrm{C}^{-1} \mathrm{~h}^{-1}\right)$ by TdR after multiplying TdR by the thymidine conversion factor (in this case $1.1 \times 10^{18}$ cells $\mathrm{mol}^{-1}$ thymidine) (i.e. $\mathrm{g} \mathrm{C}^{-1} \mathrm{~h}^{-1}$ divided by cells produced $\mathrm{l}^{-1} \mathrm{~h}^{-1}=\mathrm{g} \mathrm{C}$ newly produced cell ${ }^{-1}$ ). Carbon per NCC decreased upstream with decreasing salinity (Fig. 5).

\section{DISCUSSION}

\section{Bacterial properties in the York River estuary}

Of the environmental factors measured in this study, changes in bacterial abundance were most closely related to changes in salinity and temperature (Table 2). Concentrations of organic substrates (DOC, DON) or inorganic substrates $\left(\mathrm{NH}_{4}, \mathrm{NO}_{2+3}\right.$, DIN) were 

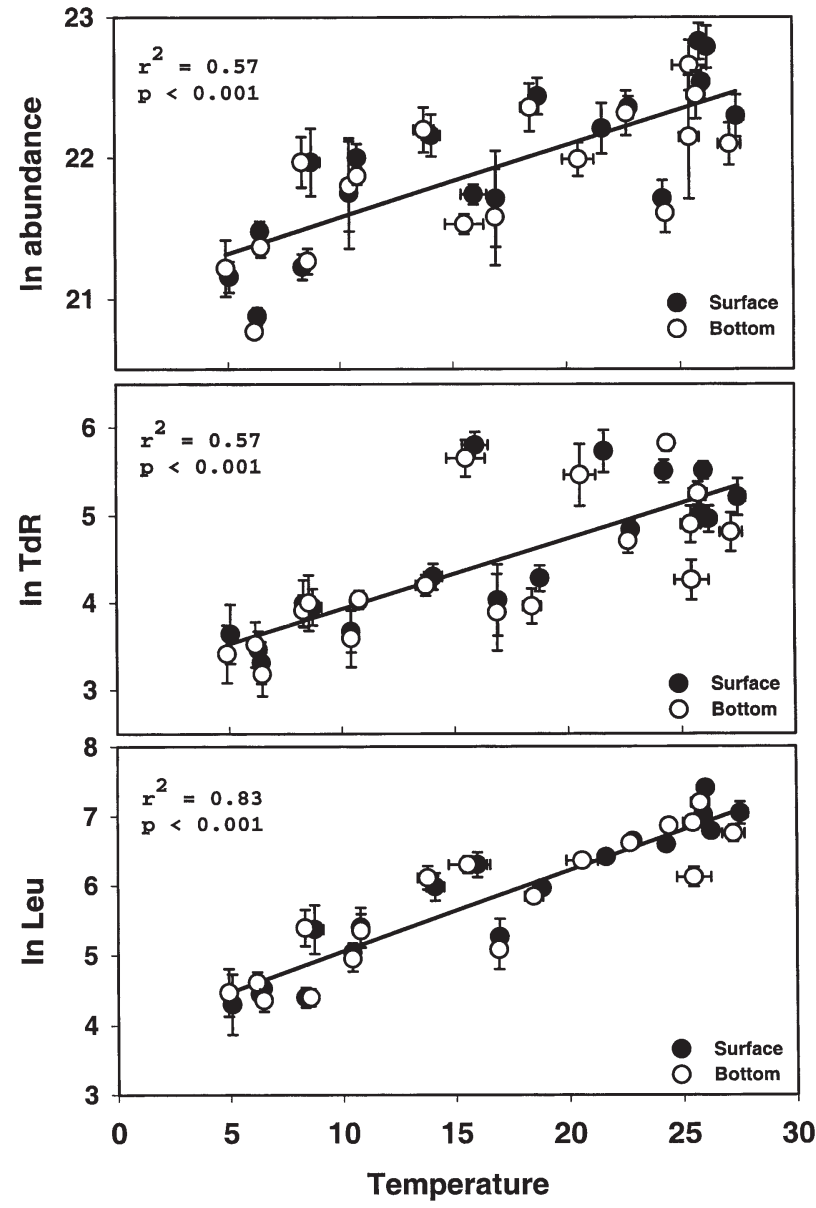

Fig. 3. Plots of mean bacterial properties of all months for each station (surface and bottom values) versus temperature. Bacterial abundance and incorporation rates were natural-log transformed to achieve homoscedasticity. Linear regression results $\left(\mathrm{r}^{2}\right)$ and significance level are in upper left of each graph. Units as in Fig. 2. Error bars are standard error of the mean

not significantly related to most bacterial properties. Bacterial dynamics in the York River estuary may actually be related to the labile fractions of DOC and DON, but changes in the concentrations of the labile fractions may be masked by variations in bulk properties. The few, weak relationships seen between bacterial properties and DOC and DON may also be because concentrations of these substrates were always in excess and bacteria growth and production were limited by other factors (Shiah \& Ducklow 1994). The relationships between bacterial properties and organic matter in the York will be examined further below.

\section{Top down controls: predation or other loss terms}

Despite the fact that both TdR incorporation and cell abundance were significantly related to tempera-

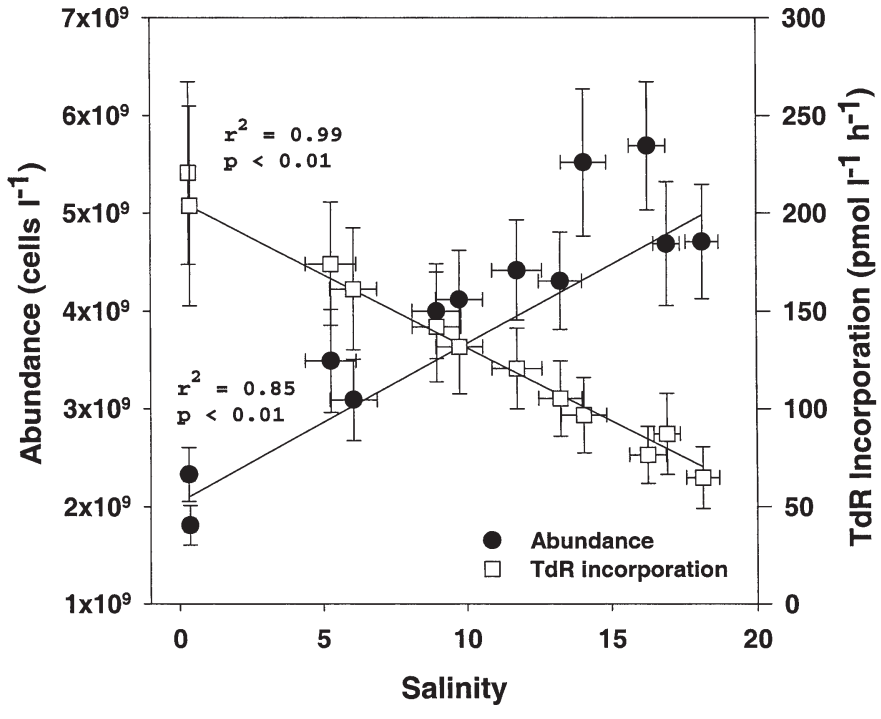

Fig. 4. Inverse pattern of bacterial abundance and TdR incorporation. Data plotted are the annual mean values at each station for the entire 2 yr sampling period. Error bars are standard error of the mean

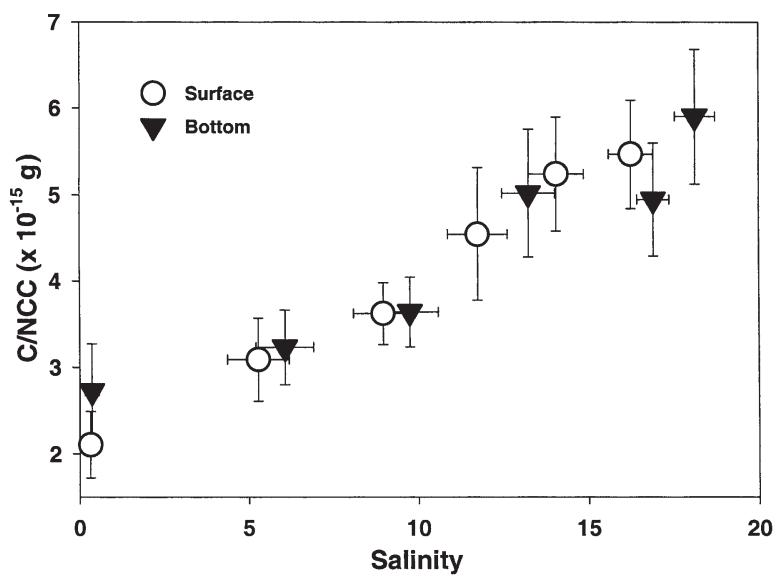

Fig. 5. Mean values of carbon per newly created cell (C/NCC) over the entire $2 \mathrm{yr}$ sampling period at each station $\left(\times 10^{-15} \mathrm{~g}\right.$ $\mathrm{C}^{-1}$ cell $^{-1}$ )

ture, TdR cell ${ }^{-1}$ was the only bacterial property not significantly related to temperature in the multiple regression models. This lack of relationship may be because TdR cell ${ }^{-1}$ was highest in the spring and fall months (Table 1) when the water temperature was warm, rather than in the summer when the temperature was maximal. TdR cell ${ }^{-1}$ depends upon the relationship between cell abundance and TdR incorporation and is a measure of specific growth rate. Thus, growth rate may reach a physiological maximum in the spring and not rise further during the warmest months. Cell abundance tended to decrease beyond a certain level of TdR incorporation (Fig. 6), indicating 
that removal processes became more important at higher temperatures and high abundance. This increase in TdR cell ${ }^{-1}$ in the fall was a consequence of greater declines in abundance than in TdR incorporation between summer and fall (Table 1). Thus the fall maxima in TdR cell ${ }^{-1}$ and Leu cell ${ }^{-1}$ suggest the relative importance of removal processes during the summer - fall transition period.

\section{Bottom-up controls: availability of labile DOM}

Another potential controlling factor of bacterial activity is the availability of labile DOM. In the York River, rainfall usually increases in the spring, increasing river discharge and bringing more run-off and more nutrients into the system (USGS; http:// water.usgs.gov). This in turn causes phytoplankton blooms in the York estuary during the spring (Sin et al. 1999). In the fall, river discharge is typically lower than in the spring (USGS; http://water.usgs.gov), but because the York River basin is heavily forested (the Chesapeake Bay Program, www.chesapeakebay.net), large amounts of organic material may be washed into the rivers and streams as upland trees lose their leaves. Although it is not clear that there were greater amounts of bulk DOC and DON in the river in the spring and fall of this study (Fig. 2), the labile fraction of the DOC and DON may have been greater during these months.

To investigate this hypothesis, the ratio of DOC to DON and the ratio of DOC to TDN were examined as potential indices of organic material lability. As the $\mathrm{C}: \mathrm{N}$ ratio increases, lability decreases and vice versa (Goldman et al. 1987, Keil \& Kirchman 1991, Cherrier

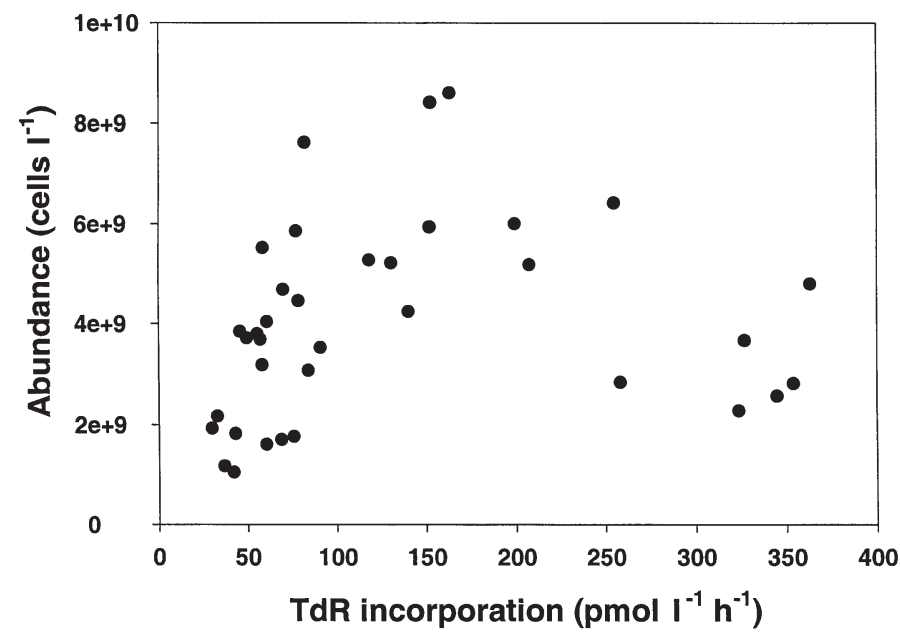

Fig. 6. Scatter plot of surface and bottom means of TdR incorporation against bacterial abundance. Data are the mean value of all stations for each month sampled et al. 1996). Since no other significant relationships were found between these measures of lability and bacterial properties, the relationships seen between TdR cell ${ }^{-1}$ and Leu cell ${ }^{-1}$ and DOC:DON must be due to the weak relationship between cell abundance and DOC:DON. Cell abundance increased as DOC:DON decreased. In other words, abundance increased with increasing lability. However, since incorporation rates did not also increase with increasing lability, this relationship is likely an artifact caused by autocorrelation between salinity and DOC:DON. It is therefore unlikely that, over the course of this study, the availability of labile organic matter in the York River, at least as measured by the DOC:DON ratio, controlled bacterial activity.

\section{Seasonal patterns (temperature)}

It is well established that temperature is an important control on estuarine bacterial dynamics (Ducklow \& Shiah 1993, Shiah \& Ducklow 1994). Since our analysis suggested that organic matter was not limiting, increases in temperature alone could stimulate production and growth rates. The relationships between bacterial properties and temperature in the York River estuary over seasonal time-scales were also strong. While other significant relationships existed, temperature clearly exhibited the strongest control over all bacterial properties other than TdR cell $^{-1}$ (Table 3 ). These results again indicate that, over the seasonal time-scales of this study, temperature rather than potential labile substrate exerted the strongest control on bacterial activity throughout the York River estuary.

\section{Spatial patterns (salinity)}

After temperature, salinity was generally the most influential factor explaining variability in bacterial properties (except year; Table 1). Bacterial properties were most strongly related to salinity in the spatial patterns model (Table 4), but the interpretation of this analysis was not as clear as for the temporal analysis. We consider that changes in salinity per se are unlikely to affect bacterial properties directly. Alternatively, some unmeasured property covarying with salinity (e.g. labile DOM) may have controlled the bacterial variables. Salinity distribution in the estuary is a consequence of the freshwater input and circulation; thus the significant correlations between salt and bacterial properties in the spatial domain indicate the influence of the freshwater input and estuarine circulation on bacterial distributions. There were, for example, 
strong negative correlations between salinity and DOC, DON, TDN, and DIN, all of which are supplied in the freshwater inflow (data not shown). These relationships raise the possibility that, although bulk DOM was not a controlling factor over time, for any particular sampling period, the concentration of dissolved substrates along the salinity gradient may have been important in the control of bacterial properties. Although inorganic $\mathrm{N}$ is an unlikely direct control on bacterial variations (e.g. inorganic nitrogen limitation of DOC utilization), nutrient limitation of phytoplankton may have influenced the supply of labile dissolved substrate flux to bacteria.

\section{Inverse pattern of abundance and TdR incorporation}

The inverse pattern of abundance and TdR incorporation found in the York River has not been reported for other estuaries. Bacterial abundance decreases downstream in some estuaries (Painchaud \& Therriault 1989), increases downstream in others (Christian et al. 1984) and sometimes exhibits mid-estuarine peaks (Shiah \& Ducklow 1993). But in all cases reported, bacterial production tended to correlate positively with bacterial abundance and showed a similar spatial distribution.

The inverse relationship between TdR incorporation and abundance indicated a strong increase in specific growth rate with distance upstream. This was demonstrated most clearly in the spring and fall when TdR cell $^{-1}$ at Stn 6 was more than double the TdR cell ${ }^{-1}$ of any other station or time (Table 1). Abundance could only remain low in the presence of high growth rates if corresponding removal processes were also high. Despite apparent high loss rates upstream, if growth rates were even slightly higher than loss rates, then river flow would allow cells to accumulate downstream. It seems clear that for the observed pattern of inverse abundance and activity to persist in the York River estuary, removal must be a strong control on bacterial distribution along the salinity gradient (Schultz \& Ducklow 2000).

Removal processes may include grazing, losses due to viral lysis, sedimentation of cells or other loss terms. Unfortunately, how much of the removal is accounted for by each process could not be specified. However, several investigations have shown that microflagellate grazing rates may be as large as bacterial production rates (Sanders et al. 1989). Regardless of the specific mechanism of removal, the inverse pattern of production and abundance illustrates the close interaction of growth, removal and circulation governing the distribution of bacteria along the estuary (Painchaud et al. 1987).

\section{Consequences of inverse pattern of abundance and production distribution}

While both Leu incorporation and TdR incorporation are used to determine production, Leu incorporation is a measure of biomass synthesis while TdR incorporation is a measure of cell division. While TdR incorporation decreased with increasing salinity to provide the pattern discussed above, Leu incorporation rates did not follow the same pattern. The ratio Leu:TdR was significantly related to salinity (data not shown). The relationship between TdR and Leu distributions suggested that circulation or freshwater inputs also influenced variations in cell division and biomass production in a systematic way. The decrease in NCC with decreasing salinity upstream occurred because TdR incorporation increased upstream, while Leu incorporation did not significantly change along the salinity gradient. The amount of carbon being assimilated into protein was more uniform, but the rate of production of new cells decreased with increasing salinity downstream. Thus, there was more carbon in the new cells downstream. This pattern occurred despite the fact that growth rate and overall average cell volume also decreased with increasing salinity. This indicates that the cells upstream may be more robust than those downstream and may be concentrating their metabolism on division rather than cell maintenance (Shiah \& Ducklow 1998). Alternatively, if more cells were damaged or only weakly active (for whatever reason), those cells could be using carbon for sustenance and maintenance rather than growth. Finally, these differences in production strategies may be due to differences in bacterial community structure along the salinity gradient (Crump et al. 1999, Schultz \& Ducklow 2000, Bouvier \& del Giorgio 2002).

\section{Phytoplankton and bacteria relationships}

Bacterial abundance and production were only weakly correlated with phytoplankton biomass (chlorophyll $a_{\text {; }}$ Tables 1, 3 \& 4). This is not unusual for estuaries, especially in this region (Findlay et al. 1991, Ducklow \& Shiah 1993). Existing relationships between bacterial abundance and activity and phytoplankton dynamics may be blurred or shifted by other processes. For example, the resuspension of sediments in shallow areas due to wind waves can be significant (Anderson 1972), making determination of ambient phytoplankton stocks difficult. Changes in bacterial community structure (Schultz \& Ducklow 2000) may change how organic substrates are utilized. Bacterial utilization of allochthonous $\mathrm{OM}$ and temporal lags between phytoplankton production and bacterial uti- 
lization will obscure such relationships. Bacterioplankton in the York River may depend to some extent upon allochthonous sources of organic matter. Such inputs of allochthonous material have been shown to disrupt the relationship between bacterial and phytoplankton properties (Painchaud \& Therriault 1989, Findlay et al. 1991).

The availability of DOM from either phytoplankton or allochthonous sources may play a large role in determining bacterial community structure in different regions of the York. Schultz \& Ducklow (2000) found 2 distinct bacterial communities in the York River separated at salinity 12 . The strong relationships between bacterial growth rate, newly-produced cells and salinity suggest the strong influence of variations in freshwater inputs in this relatively small estuarine system. We suggest that the advective timescale for bacterial cells, set by the relative rates of water flow and net growth, prevents the buildup of a mid-estuary peak in bacterial cells reported for larger systems (Ducklow et al. 2000). The pattern seems robust in the York, and should be sought in other estuaries of the same size and flow characteristics.

\section{CONCLUSIONS}

The York River displayed an unusual inverse pattern of bacterial properties along the salinity gradient. This unique pattern reflected a strong upstream stimulation of bacterial growth and of removal processes. Thus, bacteria upstream may grow more quickly than bacteria downstream, but they are also removed more quickly. However, even a small net positive growth rate would allow cells to accumulate downstream.

Bacteria in the York are affected by a large number of environmental factors with complex interactions. While it is difficult to determine which environmental parameters control bacterial properties, the data clearly show that temperature and salinity exert the most control over bacteria over seasonal and basinwide scales. Over seasonal time-scales, temperature exerted a strong influence upon bacterial processes. This influence was likely a direct physiological effect of temperature upon bacterial cells.

Although salinity was most closely related to bacterial properties over the estuary, salinity probably did not affect individual bacteria directly. Time averaged bacterial properties were strongly correlated with salinity, indicating control by properties covarying with salinity, including labile allochthonous inputs, circulation or bacterial community composition along the estuarine gradient.
Acknowledgements. We thank Bob Gammish and Charles Machen for piloting the RV 'Kingfisher' on our sampling trips. We also thank Carol Pollard and Ed Keesee of the VIMS analytical lab for processing our nutrient samples. Flynn Cunningham, Matt Church, Peter Countway, Leigh McCallister and Helen Quinby helped collect field samples. Support for this study was received from the Office of Naval Resources (contract no. N00014-93-0966), and the National Science Foundation (OCE-OPP9530734).

\section{LITERATURE CITED}

Anderson FE (1972) Resuspension of estuarine sediments by small amplitude waves. J Sediment Petrol 42:602-607

Baldwin WW, Bankston PW (1988) Measurement of live bacteria by Nomarski interference microscopy and steriologic methods as tested with macroscopic rod-shaped models. Appl Environ Microbiol 54:105-109

Bender ME (1986) The York River: a brief review of its physical, chemical and biological characteristics. Virginia Institute of Marine Science, Gloucester Point, VA

Billen G (1990) Delayed development of bacterioplankton with respect to phytoplankton: a clue for understanding their trophic relationships. In: Straskrabova V (ed) Proceedings of the fourth international workshop on the measurement of microbial activities in the carbon cycle in aquatic ecosystems. Schweizerbartische Verlagsbuchhandlung, Stuttgart, p 191-201

Boissonneault-Cellineri KR, Mehta M, Lonsdale DJ, Caron DA (2001) Microbial food web interactions in two Long Island embayments. Aquat Microb Ecol 26:139-155

Bouvier TC, del Giorgio PA (2002) Compositional changes in free-living bacterial communities along a salinity gradient in two temperate estuaries. Limnol Oceanogr 47:453-470

Burnison BK (1980) Modified dimethyl sulfoxide (DMSO) extraction for chlorophyll analysis of phytoplankton. Can J Fish Aquat Sci 37:729-733

Carpenter J (1965) The Chesapeake Bay Institute. Technique for the Winkler oxygen method. Limnol Oceanogr 10: 141-143

Cherrier J, Bauer JE, Druffel ERM (1996) Utilization and turnover of labile dissolved organic matter by bacterial heterotrophs in eastern North Pacific surface waters. Mar Ecol Prog Ser 139:267-279

Christian RR, Stanley DW, Daniel DA (1984) Microbiological changes occurring at the freshwater-seawater interface of the Neuse River estuary, North Carolina. In: Kennedy VS (ed) The estuary as a filter. Academic Press, Orlando, p 349-365

Chrost RH, Faust MA (1983) Organic carbon release by phytoplankton: its composition and utilization by bacterioplankton. J Plankton Res 5:477-493

Coffin RB, Fry B, Peterson BJ, Wright RT (1989) Carbon isotopic compositions of estuarine bacteria. Limnol Oceanogr 34:1305-1310

Cole JJ, Findlay S, Pace ML (1988) Bacterial production in fresh and saltwater ecosystems: a cross-system overview. Mar Ecol Prog Ser 43:1-10

Crump BC, Armbrust EV, Baross JA (1999) Phylogenetic analysis of particle-attached and free-living bacterial, communities in the Columbia River, its estuary, and the adjacent coastal ocean. Appl Environ Microbiol 65: 3192-3204

Day JW Jr, Hall CAS, Kemp WM, Yanez-Arancibia A (1989) Estuarine ecology. John Wiley \& Sons, New York

Ducklow HW (1982) Chesapeake Bay nutrient and plankton 
dynamics. 1. Bacterial biomass and production during spring tidal destratification in the York River, Virginia estuary. Limnol Oceanogr 27(4):651-659

Ducklow HW (2000) Bacterioplankton production and biomass in the oceans. In: Kirchman D (ed) Microbial ecology of the oceans. John Wiley \& Sons, New York, p 85-120

Ducklow HW, Carlson CA (1992) Oceanic bacterial production. In: Marshall KC (ed) Advances in microbial ecology, Vol 12. Plenum Press, New York, p 113-181

Ducklow HW, Kirchman DL (1983) Bacterial dynamics and distribution during a spring bloom in the Hudson River plume, USA. J Plankton Res 5:333-355

Ducklow HW, Shiah FK (1993) Bacterial production in estuaries. Aquatic microbiology: an ecological approach. In: Ford TE (ed) Aquatic microbiology. Blackwell Scientific Publications, Oxford, p 261-287

Ducklow HW, Schultz GE, Raymond P, Bauer JE, Shiah FK (2000) Bacterial and DOM dynamics in large and small estuaries. In: Bell CR, Brylinsky M, Johnson-Green P (eds) Microbial biosystems - new frontiers: proceedings of the 8th International Symposium on Microbial Ecology. Atlantic Canada Society for Microbial Ecology, Halifax, NS, $p$ 105-112

Eldridge PM, Sieracki ME (1993) Biological and hydrodynamic regulation of the microbial food web in a periodically mixed estuary. Limnol Oceanogr 38:1666-1679

Findlay S, Pace ML, Lints D, Cole J, Caraco NF, Peierls B (1991) Weak coupling of bacterial and algal production in a heterotrophic ecosystem: the Hudson River estuary. Limnol Oceanogr 36 2:268-278

Fuhrman JA, Azam F (1982) Thymidine incorporation as a measure of heterotrophic bacterioplankton production in marine surface waters: evaluation and field results. Mar Biol 66:109-120

Gilmour CC, Tuttle JH, Means JC (1987) Anaerobic microbial methylation of inorganic tin and estuarine sediment slurries. Microb Ecol 14:233-242

Goldman JC, Caron DA, Dennett MR (1987) Regulation of gross growth efficiency and ammonium regeneration in bacteria by substrate $\mathrm{C}: \mathrm{N}$ ratio. Limnol Oceanogr 32: 1239-1252

Gomes H, Pant A, Goes JL, Parulekar AH (1991) Heterotrophic utilization of extracellular products of phytoplankton in a tropical estuary. J Plankton Res 13:487-498

Goosen NK, van Rijswijk P, Kromkamp P, Peene J (1997) Regulation of annual variation in heterotrophic bacterial production in the Schelde estuary (SW Netherlands). Aquat Microb Ecol 12:223-232

Hobbie JE, Daley RJ, Jasper S (1977) Use of Nuclepore filters for counting bacteria by epifluorescence microscopy. Appl Environ Microbiol 33:1225-1228

Hullar MAJ, Fry B, Peterson BJ, Wright RT (1996) Microbial utilization of estuarine dissolved organic carbon: a stable isotope tracer approach tested by mass balance. Appl Environ Microbiol 62:2489-2493

Keil RG, Kirchman DL (1991) Contribution of dissolved free amino acids and ammonium to the nitrogen requirements of heterotrophic bacterioplankton. Mar Ecol Prog Ser 73: $1-10$

Kelley CA, Coffin RB (1998) Stable isotope evidence for alternative bacterial carbon sources in the Gulf of Mexico. Limnol Oceanogr 43:1962-1969

Kirchman D, K'nees E, Hodson R (1985) Leucine incorporation and its potential as a measure of protein synthesis by bacteria in natural waters. Appl Environ Microbiol 49:599-607

Koepfler ET, Kator HI, Wetzel RL, Haas LW, Webb KL (1993) Spatial and temporal bacterioplankton dynamics during destratification of the James River estuary, Virginia, USA. Mar Ecol Prog Ser 102:229-344

Lancelot C, Billen G (1984) Activity of heterotrophic bacteria and its coupling to primary production during spring phytoplankton bloom in the southern bight of the North Sea. Limnol Oceanogr 29:721-730

Miller CA, Penry DL, Gilbert PM (1995) The impact of trophic interactions on rates of nitrogen regeneration and grazing in Chesapeake Bay. Limnol Oceanogr 40:1005-1011

Nagata T, Kirchman D (1991) Release of dissolved free and combined amino acids by bacterivorous marine flagellates. Limnol Oceanogr 36:433-443

Painchaud J, Therriault JC (1989) Relationships between bacteria, phytoplankton and particulate organic carbon in the upper St. Lawrence estuary. Mar Ecol Prog Ser 56: 301-311

Painchaud J, Lefaivre D, Therriault JC (1987) Box model analysis of bacterial fluxes in the St. Lawrence Estuary. Mar Ecol Prog Ser 41:241-252

Parsons T, Maita Y, Lalli C (1984) A manual of chemical and biological methods for seawater analysis. Pergamon Press, Oxford

Revilla M, Iriarte A, Madariaga I, Orive E (2000) Bacterial and phytoplankton dynamics along a trophic gradient in a shallow temperate estuary. Estuar Coast Shelf Sci 50: 297-313

Riemann B, Bjornsen PK, Newell S, Fallon R (1987) Calculation of cell production of coastal marine bacteria based on measured incorporation of $\left[{ }^{3} \mathrm{H}\right]$ thymidine. Limnol Oceanogr 32, 2:471-476

Rublee PA, Merkel SM, Faust MA, Miklas J (1984) Distribution and activity of bacteria in the headwaters of the Rhode River estuary, Maryland, USA. Microb Ecol 10: 243-255

Sanders RW, Porter KG, Bennett SJ, DeBiase AE (1989) Seasonal patterns of bacterivory by flagellates, ciliates, rotifers, and cladocerans in a freshwater planktonic community. Limnol Oceanogr 34:673-687

Schultz GE Jr, Ducklow HW (2000) Changes in bacterioplankton metabolic capabilities along a salinity gradient in the York River estuary, Virginia, USA. Aquat Microb Ecol 22:163-174

Shiah FK, Ducklow HW (1994) Temperature and substrate regulation of bacterial abundance, production and specific growth rate in Chesapeake Bay, USA. Mar Ecol Prog Ser 103:297-308

Shiah FK, Ducklow HW (1995) Multiscale variability in bacterioplankton abundance, production, and specific growth rate in a temperate salt-marsh tidal creek. Limnol Oceanogr 40:55-66

Shiah FK, Ducklow HW (1998) Bacterioplankton growth responses to temperature and chlorophyll variations in estuaries measured by thymidine:leucine incorporation ratio. Aquat Microb Ecol 13:151-159

Simon M, Azam F (1989) Protein content and protein synthesis rates of planktonic marine bacteria. Mar Ecol Prog Ser 51:201-213

Sin Y, Wetzel RL, Anderson IC (1999) Spatial and temporal characteristics of nutrient and phytoplankton dynamics in the York River estuary, Virginia: analyses of long term data. Estuaries 22:260-275

Smith DC, Azam F (1992) A simple, economical method for measuring bacterial protein synthesis rates in seawater using ${ }^{3} \mathrm{H}$-leucine. Mar Microb Food Webs 6:107-114

Watson SW, Novitsky TJ, Quinby HL, Valois FW (1977) Determination of bacterial number and biomass in the marine environment. Appl Environ Microbiol 33:940-946 
White P, Kalff J, Rasmussen J, Gasol J (1991) The effect of temperature and algal biomass on bacterial production and specific growth rate in freshwater and marine habitats. Microb Ecol 21:99-118

Williams P, Bauer J, Robertson K, Wolgast D, Ocelli M (1993) Report on DOC and DON measurements made at Scripps Institution of Oceanography, 1988-1991. Mar Chem 41:271-281

Editorial responsibility: James Hollibaugh, Athens, Georgia, USA
Winter PED, Schlacher TA, Baird D (1996) Carbon flux between an estuary and the ocean: a case for outwelling. Hydrobiol 337:123-132

Wright RT, Coffin RB, Lebo ME (1987) Dynamics of planktonic bacteria and heterotrophic microflagellates in the Parker Estuary, northern Massachusetts. Cont Shelf Res 7: 1383-1397

Submitted: August 19, 2002; Accepted: November 1, 2002 Proofs received from author(s): December 6, 2002 